\title{
Middle Weichselian interstadial deposit at Petäjäselkä, Northern Finland
}

\author{
Pertti Sarala, Tiina Eskola
}

\begin{abstract}
:
An inter-till stratified sediment deposit with intervening organic layer was identified at Petäjäselkä, northern Finland. The deposit lay under a peat bog and was itself underlain by a 3-m thick basal till bed. Sampling by percussion drilling revealed an intervening 1-15 cm thick organic layer between stratified sands at 5.5-6.0 m depth. The pollen composition of the organic layer was dominated by Pinus-Betula and its radiocarbon age was 35,300 $\pm 600 \mathrm{BP}\left({ }^{14} \mathrm{C}\right)$. The estimated age of the sands under the organic layer, determined by the OSL method, was $72.6 \pm 21.3 \mathrm{ka}$ and $58.1 \pm 17.0 \mathrm{ka}$ at two different sampling points, while that of the sand above the organic material was $31.8 \pm 5.6 \mathrm{ka}$ at one of these points. Based on these dating results, the inter-till stratified sands with intervening organic layer represent the Middle Weichselian interstadial. This provides further evidence of an ice-free period in northern Finland, in the centre of the Scandinavian Ice Sheet, during the Middle Weichselian
\end{abstract}

[Interstadiale Ablagerungen des Mittel-Weichsel aus Petäjäselkä, Nord-Finnland]

\begin{abstract}
Kurzfassung: $\quad$ In Petäjäselka (Nord-Finnland) wurde ein geschichtetes Sedimentpaket mit einer zwischengeschalteten Organiklage nachgewiesen, welches in Till der Grundmoräne eingebettet war. Die Grundmoräne hatte eine Mächtigkeit von $3 \mathrm{~m}$ und wurde von einem Moor überlagert. Durch Rammkernbohrungen war dann eine 1-15 cm mächtige Organiklage nachweisbar, die in Tiefen von 5.5-6.0 m jeweils in Sanden eingebettet war. Der organische Horizont ist durch eine Pinus-Betula-Gemeinschaft und ein absolutes Alter von 35,300 $\pm 600 \mathrm{BP}\left({ }^{14} \mathrm{C}\right)$ gekennzeichnet. Die unterlagernden Sande wurden an zwei Lokalitäten per OSL auf Alter von $72.6 \pm 21.3$ ka und $58.1 \pm 17.0$ ka datiert. Für den überlagernden Sand wurde per OSL an einer der Lokalitäten ein Alter von $31.8 \pm 5.6$ ka bestimmt. Den Datierungsergebnissen zufolge repräsentieren die in den Till eingebetten Sande mit dem Organikhorizont ein Interstadial des Mittel-Weichsel. Desweiteren lässt sich daraus für Nord-Finnland eine eisfreie Phase während des Mittel-Weichsels im Zentrum des Skandinavischen Eisschildes ableiten.
\end{abstract}

Keywords: Quaternary, Middle Weichselian, interstadial, glacial stratigraphy, Finland

Addresses of authors: P. Sarala*, Geological Survey of Finland, P.O. Box 77, FI-96101 Rovaniemi, Finland. T. Eskola, Institute of Geosciences, University of Oulu, P.O. Box 3000, FI-90014, Finland. *Corresponding author E-Mail: pertti.sarala@gtk.fi

\section{Introduction}

The Middle Weichselian interstadials in the central part of the Scandinavian Ice Sheet (SIS) have been studied extensively during the past decade (HeLmens et al. 2000, Olsen 2002, Houmark-Nielsen \& KJær 2003, LunkKa et al. 2004, Svendsen et al. 2004, Kalm 2006, Alexanderson Murray 2007, KrzyszKowski \& Kuszell 2007, SATKunas et al. 2009, ENGELs et al. 2010). In Finland, particular attention has been focused on the stratified inter-till layers observed mainly in northern and western Finland (MÄKINEN 2005, SARAla 2005, Helmens et al. 2007, Auri et al. 2008, SAloNEN et al. 2009, SARALA et al. 2010). The aim of the present study was to find further evidence on the extent and timing of the Weichselian interstadials. The main method used was stratigraphical interpretation, supported by Optically Stimulated Luminescence (OSL) and radiocarbon $\left({ }^{14} \mathrm{C}\right)$ dating. Paleontological studies were conducted on material from the organic layer.

The study sites in Finland were mainly old stratigraphical key sites at which organic-stratified sediment interlayers have been observed (e.g. HiRvas 1991). These sites were first studied during the 1970s and 1980s, when dating was based on interpretation and correlation of paleontological records (pollen and diatoms) rather than the ${ }^{14} \mathrm{C}$ method or various luminescence methods. This was due to the limitations and/or unreliability of those methods at that time (NENONEN 1995). However, some new observations were made during the past decade in other contexts, e.g. during test excavations, till sampling and other surficial geological research carried out in poorly studied areas (SARALA et al. 2005, SARALA 2008).

One of the new study sites is Petäjäselkä in northern Finland, where an inter-till stratified sediment deposit with intervening organic layer was found in a peat bog. Petäjäselkä is located in the Central Finnish Lapland, about $150 \mathrm{~km}$ inside the Arctic Circle (Fig. 1). This area was the core component of the SIS and the site of the latest ice divide zone (SARAla \& OJala 2008). A percussion drilling programme for geochemical exploration of the till was carried out in the area in 2005 and organic material was found in two of the drilling holes. In 2008, these two sampling sites were re-sampled by percussion drilling.

\section{Methods}

Sampling was carried out using percussion drilling with plastic tubes $3.7 \mathrm{~cm}$ in diameter (Fig. 2) and $1 \mathrm{~m}$ in length. The sediment cores were logged and the results described in the stratigraphy log (Fig. 3) using lithofacies classifica- 


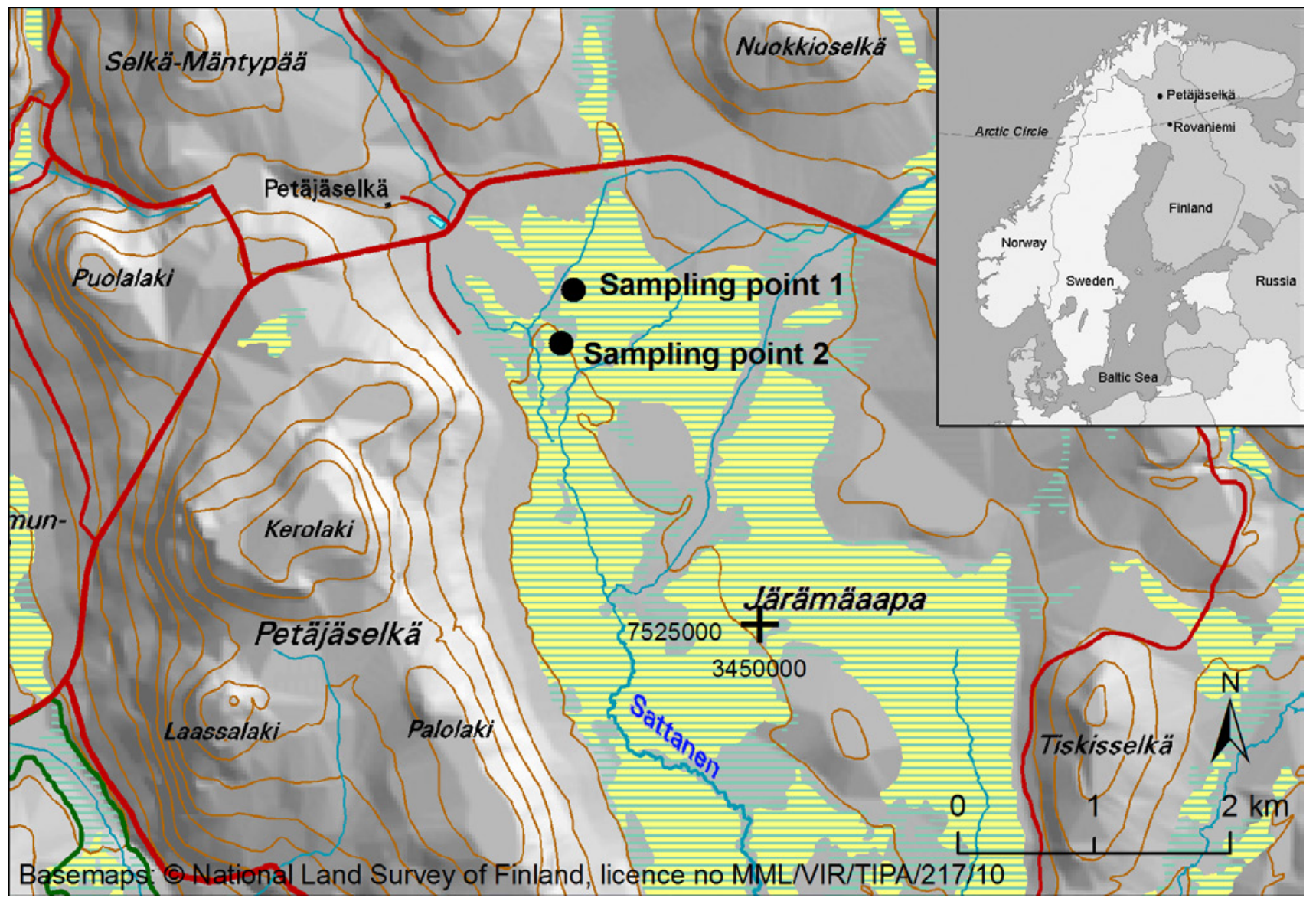

Fig. 1. Location of the study area and the two sampling sites in the färämäaapa peat bog, Petäjäselkä, northern Finland.

Abb. 1. Lage des Untersuchungsgebietes und der beiden Probenahmestellen im färämäaapa Moor bei Petäjäselkä, Nord-Finnland.

tion. One sample from the organic layer was analyzed for pollen content and the total pollen count $(\Sigma \mathrm{P})$ was calculated from the percentage of terrestrial plants (trees, shrubs, dwarf shrubs and herbs). Spores were calculated from the total pollen count and spores $(\Sigma \mathrm{P}+$ spores). A pollen diagram was compiled using the Tilia (GRImm 1991-1993) and TGView (GRIMm 2004) software.

Samples were taken for dating from the organic layer $\left({ }^{14} \mathrm{C}\right.$ dating) and from the stratified sediments above and below that layer (OSL dating). Samples for OSL dating were covered with black plastic bags to avoid damage by sunlight. The dating analysis, using quartz grains, was based on the SAR protocol described by MURRAY \& WinTLE (2000) and was performed in the Dating Laboratory of the University of Helsinki, Finland. ${ }^{14} \mathrm{C}$ dating was performed on bulk samples at the Poznań Radiocarbon Laboratory, Poland.

\section{Results}

\subsection{Stratigraphy}

The sampling sites are situated in a peat bog area and the stratigraphy is as follows (Fig. 3):

Unit 1. At the bottom there is a silty, massive or slightly laminated, brown till unit with a thickness of more than $1 \mathrm{~m}$. The till is compact and hard to penetrate with percussion drilling. Stone content is low and pebbles are small and rounded.
Unit 2. Should be indent the basal till changes gradually to a 1-m thick, gray and massive till unit. The composition of the till matrix is still silty, but the stone content and stone size is greater.

Unit 3. This is followed by a 1-m thick stratified gravelly and/or sandy deposit that includes the intervening organic layer (Fig. 2). The bottom of the deposit consists of a sand layer (20-30 cm thick) that is mainly massive, although some graded beddings can be found as a mark of streaming water. Above this there is a sharp transition to the organic layer (Fig. 2b). The organic layer is $1-15 \mathrm{~cm}$ thick and its structure is massive. Above the organic layer there is a gradual transition to an approx. $40-50 \mathrm{~cm}$ thick deposit of massive and sandy gravels.

Unit 4. Above the gravels is a $1.5-3 \mathrm{~m}$ thick till unit composed mainly of sandy or silty matrix with some thin sandy layers. Stone content is low but some larger boulders (diameter $20-50 \mathrm{~cm}$ ) are present. The transition between this unit and that both above and below is gradual.

Unit 5. On the top of the profile lies a modern, Holocene peat cover of 2-3 m depth. In mire classification the peat type is aapa mire, the most common type in central Finnish Lapland. The peat in aapa mires is most typically composed of brown moss (Bryales) and residues of sedge-like plants. The surface vegetation of the mire is composed of mosses such as Sphagnum spp. and sedges such as Carex spp., but also many sprigs of e.g. Arctic birch (Betula nana). One of the typical plants is bogbean (Menyanthes trifoliata). 


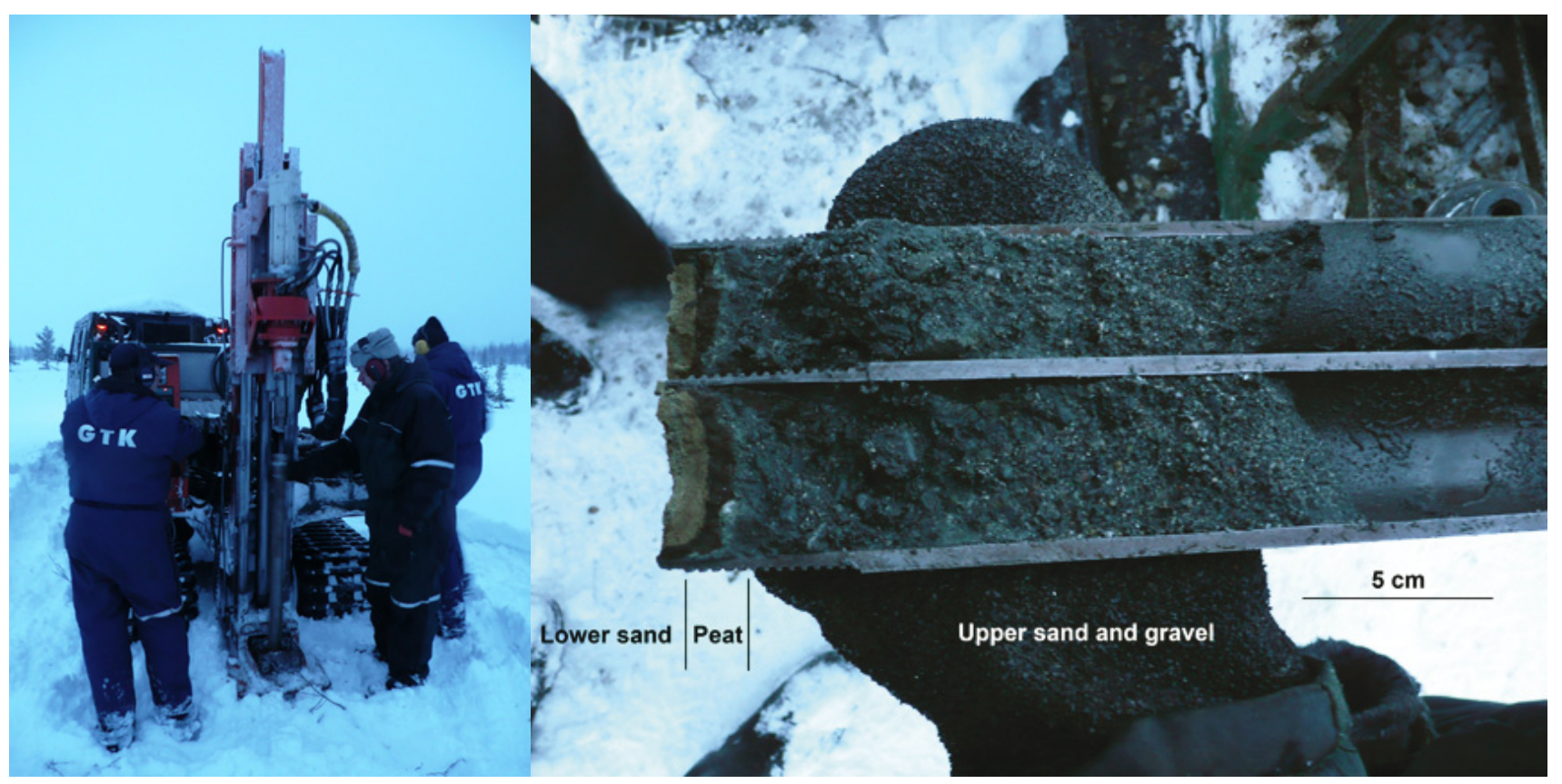

Fig. 2. a) Percussion drilling in färämäaapa and b) longitudinal section of $3.5 \mathrm{~cm}$ diameter percussion drilling core from färämäaapa, showing the $1 \mathrm{~cm}$ thick organic layer between sands and gravels (fanuary 2008. Photos: P. Sarala).

Abb. 2. a) Schlagbohrgerät in färämäaapa und b) Längsschnitt Bohrkern aus dem färämäaapa Moor (Durchmesser $3.5 \mathrm{~cm}$ ) mit der $1 \mathrm{~cm}$ mächtigen Organiklage zwischen Sanden und Kiesen (Januar 2008, Fotos: P. Sarala).

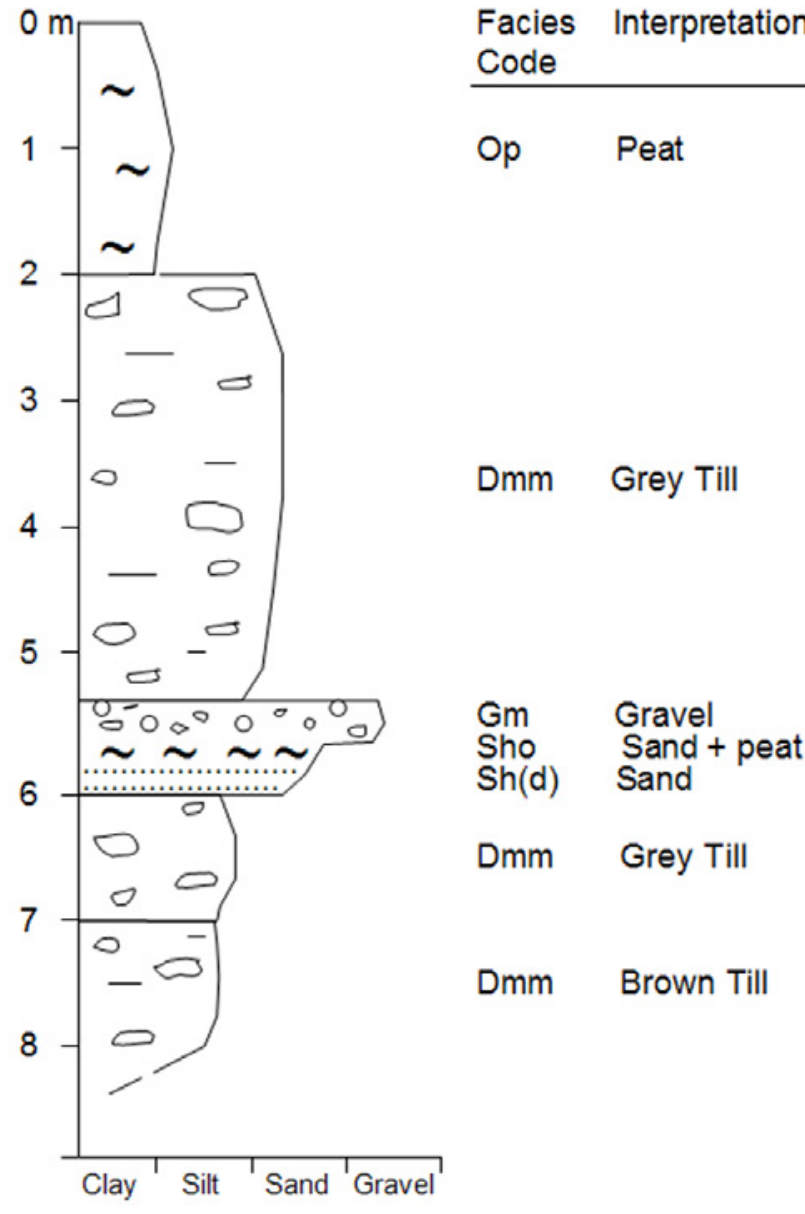

Fig. 3. Stratigraphy of the färämäaapa area as shown by the stratigraphy log of the sediment core at sampling point 2. The inter-till sediment is 1-2 $m$ thick, with an intervening 1-15 cm thick organic layer.

Abb. 3. Stratigraphie des färämäaapa Moors wie sie aus der Schichtenfolge an der Probenahmestelle 2 ableitbar ist. Das Sedimentpaket im Geschiebemergel ist 1-2 $m$ dick und wird durch eine 1-15 cm dicke Organiklage gegliedert.

\subsection{Pollen composition of the inter-till deposit}

Pollen analyzes carried out on the organic layer (Fig. 4). The percentage of tree pollens in the total pollen count in the layer was quite constant, varying from $67.8 \%$ to $74.3 \%$. Pinus was the dominant tree pollen, comprising $30.8-42.6 \%$, while Betula comprised 29.1-33.3\%. Other tree pollens present were Alnus (1.2-2.0\%), Picea (0.6-3.0\%) and Populus $(0.3 \%)$. One pollen grain of Quercus and one of Carpinus were also found (probably long-distance transportation). The non-arboreal pollen (NAP) was from shrubs such as Betula nana (0.5-2.3\%), Salix $(<0.5 \%)$ and funiperus $(<0.5 \%)$ and dwarf shrubs such as Empetrum $(<0.5 \%)$, Ledum $(<0.5 \%)$ and Vaccinium (0.5\%). Cyperaceae was the dominant herb family, comprising 17.9 to $27.7 \%$ of total pollen. Low levels of pollen from different herbs (e.g. Filipendula, funcus, Poaceae, Potentilla, Ranunculaceae, Rubus ideaus, Rumex acetosella, Solidago) were also present. Spores of Lycopodium annotium $(<0.5 \%)$, Polypodiaceae $(<1 \%)$, Selaginella selaginoides $(<0.5 \%)$ and Sphagnum (3.1-14.2\%) were identified.

\subsection{Age of the deposit}

Three gravel/sand samples were dated, one from under the organic layer at each of the two sampling points and one from above the organic layer at sampling point 1 . The OSL age of the sand under the organic layer was found to be $72.6 \pm 21.3 \mathrm{ka}$ and $58.1 \pm 17.0 \mathrm{ka}$ for sampling point 1 and 2 , respectively, although having relatively wide variations. The OSL age of the sand above the organic layer (sampling point 1) was $31.8 \pm 5.6 \mathrm{ka}$.

${ }^{14} \mathrm{C}$ dating was carried out on material from the organic layer, at a depth of about $6.4 \mathrm{~m}$ at sampling point 1 and $5.5 \mathrm{~m}$ at sampling point 2 . The age of the peat at sampling point 1 was $35,300 \pm 600 \mathrm{BP}$. However, the other sample 


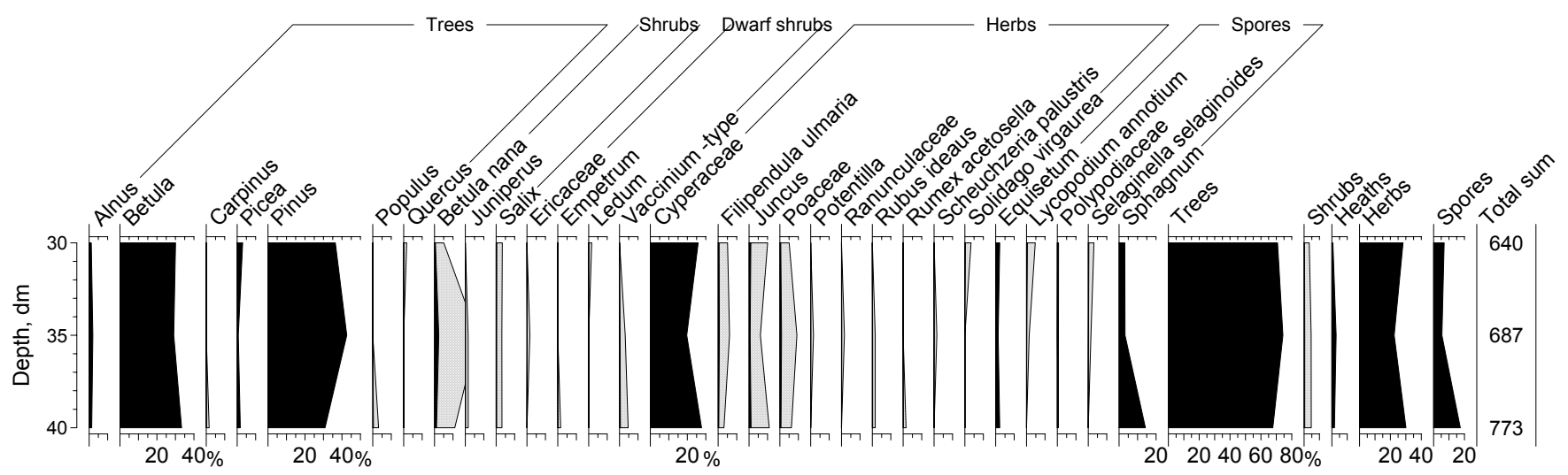

Fig. 4. Pollen diagram of the $15 \mathrm{~cm}$ thick organic layer at sampling point 2, Järämäaapa. Grey curves show $10 x$ magnifications.

Abb. 4. Pollendiagramm der $15 \mathrm{~cm}$ mächtigen Organiklage an Probenahmestelle 2 im färämäaapa Moor. Die grauen Kurven zeigen die 10fache Überhöhung.

was contaminated with peat from the bottom of the modern mire and was found to have an age of $6,900 \pm 60 \mathrm{BP}$, i.e. from the Holocene period.

The ages are in line with the stratigraphy, which indicates deposition of the bottommost sediments at the end of the Early Weichselian, followed by Middle Weichselian sedimentation.

\section{Discussion}

Northern Finland is situated in the central part of SIS and has been influenced by several cold periods since the Early Weichselian (SvENDSEN et al. 2004). There were at least two glaciation phases during the Early and/or Middle Weichselian period, with an intervening period of about $20 \mathrm{ka}$ (Helmens et al. 2000, 2007, SARAla 2005). For that reason, older stratified sediments have been available for younger erosion and re-deposition processes. The mixture of older and younger sediments is probably the reason for the rather large variation in the oldest OSL ages. However, the finite radiocarbon age of the organic layer is reliable and indicates the relative age of deposition. It confirms Middle Weichselian origin, although there is a possibility of earlier organic matter formation if the layer was contaminated by the younger carbon during later glacial processes or it was influenced by the groundwater. The radiocarbon age can also be somewhat older in calendar years but still correlates well with other age determinations of the Middle Weichselian deposits in northern Finland and Sweden (e.g. Korpela 1969, Helmens et al. 2000, 2007, HÄttestrand \& RoBertsson 2010). The Middle Weichselian interstadial deposits in central and southern Lapland have also been described by Mäkinen (2005), SARAla (2005, 2008) and SARALA et al. (2010).

Should be indent the majority of the pollen grains in the inter-till organic layer were somewhat decayed and crumbling, but still clearly identifiable. The organic matter was most probably transported and re-deposited in the sediment. For that reason, interpretation of the vegetation is quite difficult. However, the general spectrum of modern pollen samples from northern Fennoscandia suggests either tundra vegetation or open birch (sparse) forest (Prentice 1978, Seppä et al. 2002). The pollen levels of Pinus and Betula suggest that the timberline for Pinus and Betula cannot be far away from the Petäjäselkä site (Prentice 1978, Hicks 2001, SEPPÄ et al. 2002).

The same rich composition of tree pollen has been reported for example at Sokli, eastern Finnish Lapland (Helmens et al. 2000, Bos et al. 2009). Helmens et al. (2000) reported relatively high proportions of Pinus and Betula pollen (borehole 900, depth 7.81-7.07 m). The high amount of Juniperus and Cyperaceae pollen indicates the same vegetation environment. Bos et al. (2009) studied clay-silt lacustrine sediments at Sokli, dated early MIS 3 (so-called Tulppio Interstadial) and found similarities e.g. with the values of Betula, Alnus, Picea and Cyperaceae. Those authors concluded that there is a possibility of secondary origin tree pollen from older (e.g. Eemian) deposits.

Pollen records for Riipiharju, northern Sweden, are to some degree comparable (Riipiharju II, LPAZ2) (HÄtTEstrand \& Robertsson 2010). A significant difference from the Petäjäselkä profile is the absence of Pinus pollen. However, it should be noted that comparisons between these sites are not straight-forward, because in the case of Sokli and Riipiharju the sample material mainly consisted of mineral material instead of organic material.

The inter-till organic sediment layer is only about $1 \mathrm{~m}$ thick at the Petäjäselkä site and for that reason is scarcely representative of the whole 40-ka deposition history. The layer indicates re-deposition in separate phases. However, the stratigraphy is supported by the chronological data and indicates the occurrence of ice-free period(s) during the Middle Weichselian.

\section{Conclusions}

The stratigraphical studies at Petäjäselkä form part of a larger project aimed at updating the knowledge of glacial chronology in the central part of the SIS in northern Finland. Another aim is to provide new evidence about the existence and number of Weichselian interstadials. Our dating results for Petäjäselkä proved that the inter-till stratified deposit with intervening organic layer represents the Middle Weichselian interstadial. The ice-free period could have lasted at least $20 \mathrm{ka}$ and the vegetation represents Pinus and Betula-dominated forests that are still typical of 
the area. The organic sediment deposit at Petäjäselkä and other interstadial deposits found in central and southern Finnish Lapland clearly show that northern Finland was ice-free at least once during the Middle Weichselian period.

\section{Acknowledgements}

Support for the study was provided by the Geological Survey of Finland and the University of Oulu. Mr. Kalervo Rauhala, Mr. Kauko Mokko and Mr. Jukka Takalo are thanked for their assistance during the sampling. Three anonymous referees are acknowledged for the constructive criticism of the manuscript. Dr. Mary McAfee corrected the English of the manuscript.

\section{References}

Alexanderson, H. \& Murray. A.S. (2007): Was southern Sweden ice free at 19-25 ka, or were the post LGM glacifluvial sediments incompletely bleached? - Quaternary Geochronology, 1-4: 229-236.

Auri, J., Breilin, O., Hirvas, H., Huhta, P., Johansson, P., Mäkinen, K. Nenonen, K. \& SARAla, P. (2008): Tiedonanto eräiden myöhäispleistoseenikerrostumien avainkohteiden ajoittamisesta Suomessa. - Geologi, 60: 68-74.

Bos, J.A.A., Helmens, K.F., Bohncke, S.J.P., Seppä, H. \& Birks, H.J.B (2009): Flora, vegetation, and climate at Sokli, northeastern Fennoscandia, during the Weichselian Middle Pleniglacial. - Boreas, 38: 335-348.

Engels, S., Helmens, K.F., VÄliranta, M., Brooks, S.J. ひ Birks, J.B. (2010): Early Weichselian (MIS 5d and 5c) temperatures and environmental changes in northern Fennoscandia as recorded by chironomids and macroremains at Sokli, northeast Finland. - Boreas, 39: 689-704.

GRIMM, E. (1991-1993): TILIA 2.0 version b.4 (computer software). Illinois State Museum.

Grimm, E. (2004): TGView version 2.0.2 (computer software). Illinois State Museum.

HÄttestrand, M. ひ Robertsson, A.-M. (2010): Weichselian interstadials at Riipiharju, northern Sweden - interpretation of vegetation and climate from fossil and modern pollen records - Boreas, 39: 296-311.

Helmens, K., RäsÄnen, M., Johansson, P., Jugner, H. \& Korjonen, K. (2000): The Last Interglacial-Glacial cycle in NE Fennoscandia: a nearly continuous record from Sokli (Finnish Lapland). - Quaternary Science Review, 19: 1605-1623.

Helmens, K., Johansson, P., RÄsÄnen, M., Alexanderson, H. ひ Eskola, K. (2007): Ice-free intervals continuing into marine isotope stage 3 at Sokli in the central area of the Fennoscandian glaciations. - Bulletin of the Geological Society of Finland, 79: 17-39.

Hicks, S. (2001): The use of annual arboreal pollen deposition values for delimiting tree-lines in the landscape and exploring models of pollen dispersal. - Review of Palaeobotany and Palynology, 117: 1-29.

Hirvas, H. (1991): Pleistocene stratigraphy of Finnish Lapland. - Geological Survey of Finland, Bulletin, 354: 123 p.

Houmark-Nielsen, M. ¿ KJÆR, K.H. (2003): Southwest Scandinavia, 40-15 kyr BP: palaeogeography and environmental change. - Journal of Quaternary Science, 18: 769-786. DOI: $10.1002 /$ jqs.802

KALM, V. (2006): Pleistocene chronostratigraphy in Estonia, southeastern sector of the Scandinavian glaciation. - Quaternary Science Review, 25: $960-975$

Korpela, K. (1969): Die Weichsel-Eiszeit und ihr Interstadial in Peräpohjola (nördliches Nordfinnland) im Licht von submoränen Sedimenten. - Annales Academiae Scientiarum Fennicae, A III 99: 1-108.

Krzyszkowski, D. \& Kuszell, T. (2007): Middle and Upper Weichselian
Pleniglacial fluvial erosion and sedimentation phases in Southwestern Poland, and their relationship to Scandinavian ice sheet buildup and retreat. - Annales Societatis Geologorum Poloniae, 77: 17-38.

LunkKa, J.P., Johansson, P., SAARnisto, M. \& SAllasmaA, O. (2004): Glaciation of Finland. - In: Ehlers, J. \& Gibbard, P.L. (Ed.): Quaternary Glaciations - Extent and Chronology: 93-100, Elsevier.

MäKInEN, K. (2005): Dating the Weichselian deposits of southwestern Finnish Lapland. - Geological Survey of Finland, Special Paper, 40: 67-78.

Murray, A. $\mho$ Wintle, A. (2000): Luminescence dating of quartz using an improved single-aliquot regenerative-dose protocol. - Radiation Measurements, 32: 57-73.

Nenonen, K. (1995): Pleistocene stratigraphy and reference sections in southern and western Finland. - PhD thesis, Geological Survey of Finland: 94 p. +7 original papers, Kuopio.

OLSEN, L. (2002): Mid and Late Weichselian, ice-sheet fluctuations northwest of the Svartisen glacier, Nordland, northern Norway. - Norges geologiske undersøkelse, Bulletin, 440: 39-52.

Prentice, I. C. (1978): Modern pollen spectra from lake sediments in Finland and Finnmark, north Norway. - Boreas, 7: 131-153.

Salonen, V.-P., KaAKinen, A., Kultti, S., Miettinen, A., Eskola, K.O. \& LunkKA, J.P. (2008): Middle Weichselian glacial event in the central part of the Scandinavian Ice Sheet recorded in the Hitura pit, Ostrobothnia, Finland. - Boreas, 37: 38-54. DOI: 10.1111/j.15023885.2007.00009.x

SARALA, P. (2005): Glacial morphology and dynamics with till geochemical exploration in the ribbed moraine area of Peräpohjola, Finnish Lapland. - PhD thesis, Geological Survey of Finland: 17 p. +6 original papers, Espoo.

SARAlA, P. (2008): New OSL dating results in the central part of Scandinavian Ice Sheet. - In: LISICKI, S. (ed.): Quaternary of the Gulf of Gdansk and Lower Vistula regions in northern Poland, sedimentary environments, stratigraphy and palaeogeography. International field symposium of the INQUA Peribaltic Group, Frombork, September 14-19, 2008. Warszawa, Polish Geological Institute, 49-50.

Sarala, P.O., Johansson, P.W., Jungner, H. \& Eskola, K.O. (2005): The Middle Weichselian interstadial: new OSL dates from southwestern Finnish Lapland. - In: Kolka, V. \& Korsakova, O. (eds.): Quaternary geology and landforming processes: proceedings of the international field symposium, Kola Peninsula, NW Russia, September 4-9, 2005 Apatity, Kola Science Centre RAS, 56-58.

SARALA, P. \& OJALA, V.J. (2008): Implications of complex glacial deposits for till geochemical exploration: Examples from the central Fennoscandian ice sheet. - In: StefÁnsson, Ó. (ed.): Geochemistry Research Advances, Chapter 1: 1-29. Nova Publishers, New York.

Sarala, P., Pihlaja, J., Putkinen, N. \& Murray, A. (2010): Composition and origin of the Middle Weichselian interstadial deposit in Veskoniemi, Finnish Lapland. - Estonian Journal of Earth Sciences, 59 (2) 117-124. DOI: 10.3176/earth.2010.2

Satkunas, J., Grigiene, A., Jusiene, A., Damusyte, A. \& Mazeika, J. (2009): Middle Weichselian palaeolacustrine basin in the Venta river valley and vicinity (northwest Lithuania), exemplified by the Purviai outcrop. - Quaternary International, 207: 14-25.

Seppä, H., Nyman, M., Korhola, A. \& Weckström, J. (2002): Changes of tree-lines and alpine vegetation in relation to post-glacial climate dynamics in northern Fennoscandia based on pollen and chironomid records. - Journal of Quaternary Science, 17: 287-301.

Svendsen, J., Alexanderson, H., Astakhov, V., Demidov, I., Dowdeswell, J., Funder, S., Gataullin, V., Henriksen, M., Hjort, C., Houmark-Nielsen, M., Hubberten, H., Ingolfsson, O., Jakobsson, M., KJÆr, K., Larsen, E., Lokrantz, H., LunkKa, J.-P., Lyså, A., Mangerud, J., Matiouchkov, A., Murray, A., Möller, P., Niessen, F., Nikolskaya, O., Polyak, L., SaArnisto, M., Siegert, C., Siegert, M., Spielhagen, R. \& Stein, R. (2004): Late Quaternary ice sheet history of northern Eurasia. - Quaternary Science Reviews, 23: $1229-1271$. 